\title{
GLACIER-BED LANDFORMS OF THE PRAIRIE REGION OF NORTH AMERIGA*
}

\author{
By S. R. Moran, \\ (Geology Division, Alberta Research Council, I I 3 I 5 87 Avenue, Edmonton, Alberta T6G 2C2, \\ Canada) \\ Lee Clayton, \\ (Department of Geology, University of North Dakota, Grand Forks, North Dakota 58202, \\ U.S.A.)
}

R. LeB. HooKe,

(Department of Geology and Geophysics, University of Minnesota, I08 Pillsbury Hall, 310 Pillsbury Drive S.E., Minneapolis, Minnesota 55455, U.S.A.)

M. M. Fenton, and L. D. AndriasheK

(Geology Division, Alberta Research Council, I I 3 I 5 87 Avenue, Edmonton, Alberta T6G $2 \mathrm{C}_{2}$, Canada)

Abstract. Two major types of terrain that formed at or near the bed of Pleistocene continental ice sheets are widespread throughout the prairie region of Canada and the United States. These are (I) glacial-thrust blocks and source depressions, and (2) streamlined terrain.

Glacial-thrust terrain formed where the glacier was frozen to the substrate and where elevated porepressure decreased the shear strength of the substrate to a value less than that applied by the glacier. The marginal zone of ice sheets consisted of a frozen-bed zone, no more than $2-3 \mathrm{~km}$ wide in places, within which glacial-thrust blocks are large and angular. Up-glacier from this zone, the thrust blocks are generally smaller and smoothed. Streamlined terrain begins $2-3 \mathrm{~km}$ behind known ice-margin positions and extends tens of kilometres up-glacier. Streamlined terrain formed in two ways: (I) erosion of the substrate as a consequence of basal sliding in the sub-marginal thawed-bed zone, and (2) erosional smoothing accompanied by emplacement of till in the lee of thrust blocks where they were deposited and subsequently exposed to thawed-bed conditions as a result of further advance of the glacier.

RÉsumé. Morphologie sousglaciaire dans la région de la Prairie de l'Amérique du Nord. Deux principaux types de terrains formés au fond ou près du fond de la calotte glaciaire continentale pleistocène sont répandus à travers la région de la Prairie du Canada et des États Unis. Ce sont (I) les blocs de poussée glaciaire et leur dépression d'origine et (2) les terrains d'alignement par le courant.

Les terrains de poussée glaciaire se sont formés lorsque les glaciers étaient fixés au substrat par le gel et lorsque la forte pression interstitielle a diminué la résistance au cisaillement du substrat jusqu'à une valeur inférieure à celle exercée par le glacier. Les zones marginales des calottes glaciaires ont consisté en une zone de gel sur le lit, pas plus large que 2 à $3 \mathrm{~km}$ par endroits, à l'intérieur de laquelle les blocs de poussée glaciaire sont gros et anguleux. En amont de cette zone les blocs de poussée sont en général plus petits et plus émoussés. Les terrains d'alignement par le courant commencent 2 à $3 \mathrm{~km}$ derrière les positions connues de la limite des glaces et s'étend sur ro km vers l'amont du glacier. Ces terrains d'alignement par le courant se sont formés de deux façons: ( 1 ) l'érosion du substrat, conséquence du glissement sur le fond dans la zone sub-marginale du lit en cours de dégel, et (2) l'usure par l'érosion par dépốt de débris morainiques à l'aval des blocs de poussée pré-déposés et soumis ultérieurement à des conditions de lit-dégelé à la suite d'une nouvelle avance du glacier.

Zusammenfassung. Landformen am Eisuntergrund in der Prärieregion von Nordamerika. Zwei GeländeHaupttypen, die sich am oder nahe am Untergrund pleistozäner kontinentaler Eisschilde bildeten, sind in der ganzen Prärieregion Kanadas und der Vereinigten Staaten weit verbreitet. Es sind dies: (1) Rundhökerlandschaften mit Mulden, und (2) Stromliniengeformtes Gelände.

Rundhökerlandschaften entstanden dort, wo der Gletscher am Untergrund angefroren war und wo der erhöhte Porendruck die Scherfestigkeit des Untergrundes geringer als den Scherdruck des Gletschereises werden liess. Die Randzone der Eisdecke bestand aus einer Zone gefrorenen Untergrundes, die an Stellen, wo die Rundhöker mächtig und kantig sind, nicht breiter als $2-3 \mathrm{~km}$ war. Gletscheraufwärts von dieser Zone sind die Rundhöker im allgemeinen kleiner und glatter. Stromliniengeformtes Gelände beginnt $2-3 \mathrm{~km}$ hinter bekannten Eisrandlagen und erstreckt sich etliche zehn Kilometer gletscheraufwärts. Es entstand auf zweierlei Arten: (1) Erosion des Untergrundes als Folge basalen Gleitens in der randnahen Zone aufgetauten Untergrundes, und (2) Glättung durch Erosion, begleitet von der Schutteinbettung im Lee von Rundhökern, wo der Schutt abgelagert wurde und in der Folge bei weiterem Gletschervorstoss den Bedingungen aufgetauten Untergrundes ausgesetzt war.

* Presented at the Symposium on Glacier Beds: the Ice-Rock Interface, Ottawa, I5-19 August 1978. 


\section{INTRODUGTION}

Two major types of terrain formed at the bed of continental glaciers in the prairies of North America. The first type consists of a wide range of thrust and plucked features that formed where the glacier bed was frozen and the glacier advanced by flow in the ice above the bed or by shear failure within the substrate. The second type consists of flutes, drumlins, and other longitudinal streamlined features that formed where basal sliding contributed to the movement.

The purpose of this paper is to summarize available data regarding these features and to discuss their genesis. After a summary of characteristics of these landforms, we present a discussion of their spacial distribution throughout the prairies. Finally, we present a model that relates the descriptive characteristics of the landforms to the mechanisms by which they are formed.

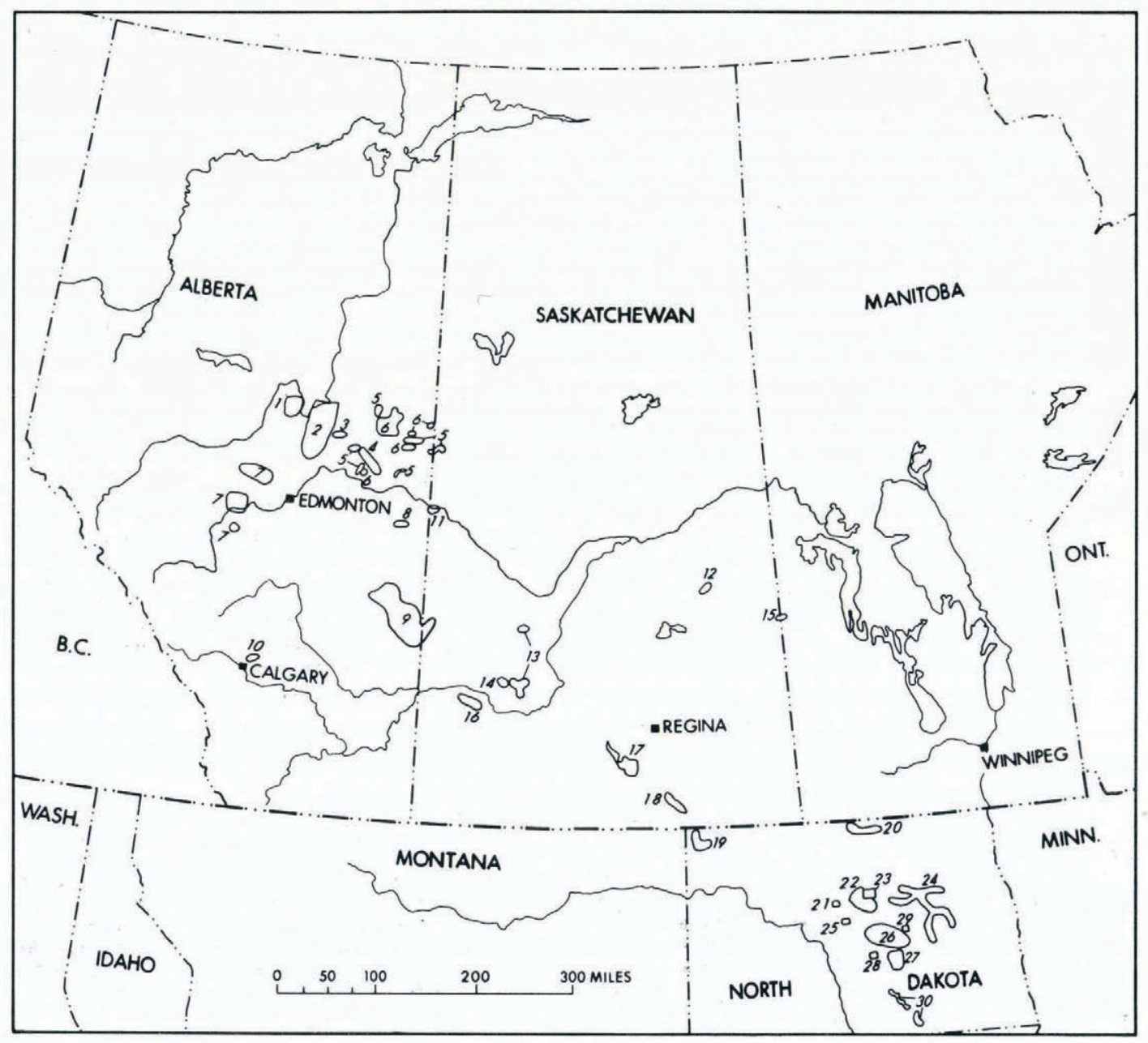

Fig. I. Map showing distribution of glacial-thrust terrain in the prairie region of $\mathcal{N}$ orth America. 
Explanation to Figure $I$

\section{Description}

I. Jumble of irregular hills; blocks up to $2.5 \mathrm{~km}^{2}$ and $90 \mathrm{~m}$ high

2. Thrust blocks streamlined, $<2 \mathrm{~km}^{2}$, $<$ I 5 m high

3. Composite thrust ridges

4. Jumble of irregular hills; blocks up to $2.6 \mathrm{~km}^{2}$ and $<30 \mathrm{~m}$ high

5. Composite thrust ridges; ridges $<$ I50 m wide, $30 \mathrm{~m}$ high

6 . Thrust hills down-glacier of depressions; in many places hills are imbricate thrust masses, and in some are streamlined and/or bounded on the lateral margin by strike-slip faults

7. Composite thrust ridges and jumbles of blocks $30-50 \mathrm{~m}$ high

8. Jumble of irregular hills; blocks generally $0.6 \mathrm{~km}^{2}$, 30-6o m high

9. Composite thrust ridges, $30-90 \mathrm{~m}$ high

10. Isolated small blocks and source depressions

II. Composite thrust ridges

12. Composite thrust ridges

13. Composite thrust ridges, height 6-1 $5 \mathrm{~m}$, wavelength $150-300 \mathrm{~m}$

14. Composite thrust ridges, 10-60 $\mathrm{m}$ high

15. Single streamlined hill, $8 \mathrm{~km}$ long, $2 \mathrm{~km}$ wide, $200 \mathrm{~m}$ high

16. Composite thrust ridges, $<5 \mathrm{~m}$ high

17. Composite thrust ridges 18. Composite thrust ridges, relief
$25-60 \mathrm{~m}$

19. Composite thrust ridges

20. Composite thrust ridges

21. Composite thrust ridges

22. Mostly isolated, relatively smooth hills, some ridges, with and without source depressions, generally I km across; and single thrust block and source depression; and single ridge thrust block and source depression; and thrust hill with up-glacier trending streamlined ridges and source depression (murdlin)

23. Composite thrust ridges

24. Straight to arcuate ridges with source depressions; and irregular, transversely elongate thrust ridges with source depressions

25. Composite thrust ridges

Unknown

26. Composite thrust ridges

27. Composite thrust ridges

28. Composite thrust ridges

29. Composite thrust ridges

30. Composite thrust ridges

\section{Composition}

Unknown; likely pebble-loam (till)

As above

As above

Pebble-loam and stratified drift

Pebble-loam, pebble-loam and shale

Mainly pebble-loam but in places includes stratified drift or shale

Shale with pebble-loam drape pebble-loam in places

Uncertain; likely pebble-loam and shale

Shale, siltstone, sandstone

Sandstone overlain by pebbleloam

Disturbed bedrock

Probably pebble-loam

Pebble-loam to depth of $15 \mathrm{~m}$

Pebble-loam, possibly bedrock

Sandstone, shale, pebble-loam

Pebble-loam and possibly bedrock

Bedrock and pebble-loam

Pebble-loam and bedrock

Sandstone and siltstone

Sandstone and siltstone

Sandstone and siltstone

Sandstone, siltstone and pebbleloam

Sandstone and siltstone

Unknown

Unknown

Unknown

Unknown

Unknown

Unknown

\section{References}

Fenton (air-photograph examination)

As above

As above

Fenton and Adriashek, 1978

Andriashek and others, I979;

Andriashek, in preparation

As above

Andriashek and others, 1979

Fenton (air photographs)

Slater, 1927; Gravenor and Bayrock, 1955; Christiansen, 1965; Green, I972

Moran, in preparation

Christiansen and Whitaker, 1973

Moran, unpublished

Christiansen, 1959; Scott, 197 I

Christiansen, 1965

Moran and Whitaker, 1969; Moran, [ $\left.{ }^{c_{1}}{ }_{971}\right]$, unpublished

St-Onge, 1967

Kupsch, 1962; Christiansen and Whitaker, [ ${ }^{\mathrm{I}}$ 976]

Parizek, 1964

Hansen, 1967

Clayton, in press

Bluemle, I97 I

Bluemle and others, 1967; Clayton, in press

Carlson and Freers, 1975; Clayton, in press

Bluemle, 1965, 1973, 1975; Bluemle and others, 1967; Carlson and Freers, I 975; Clayton, in press

Carlson and Freers, 1975; Clayton, in press

Rau and others, 1962; Feldman, 1964; Clayton and Freers, 1967 ; Denny and others, 1968

As above

Clayton, in press

Bluemle, I 975

Clayton, 1962 


\section{DESGRIPTION OF FEATURES}

\section{Glacial-thrust terrain}

Glacial-thrust terrain consists of hills and ridges composed of material that was translocated, more or less intact, by glacial plucking or thrusting and of elongate or sub-circular depressions that were the original locations of the thrust masses. Glacial-thrust terrain ranges from isolated single hills or depressions as little as $100 \mathrm{~m}$ on a side to composite thrust masses covering more than $100 \mathrm{~km}^{2}$. These features have been recognized throughout North Dakota (Fig. I : 19-30), * Saskatchewan (Fig. I : 5, 9, I I-I8), and Alberta (Fig. I : I-I0).
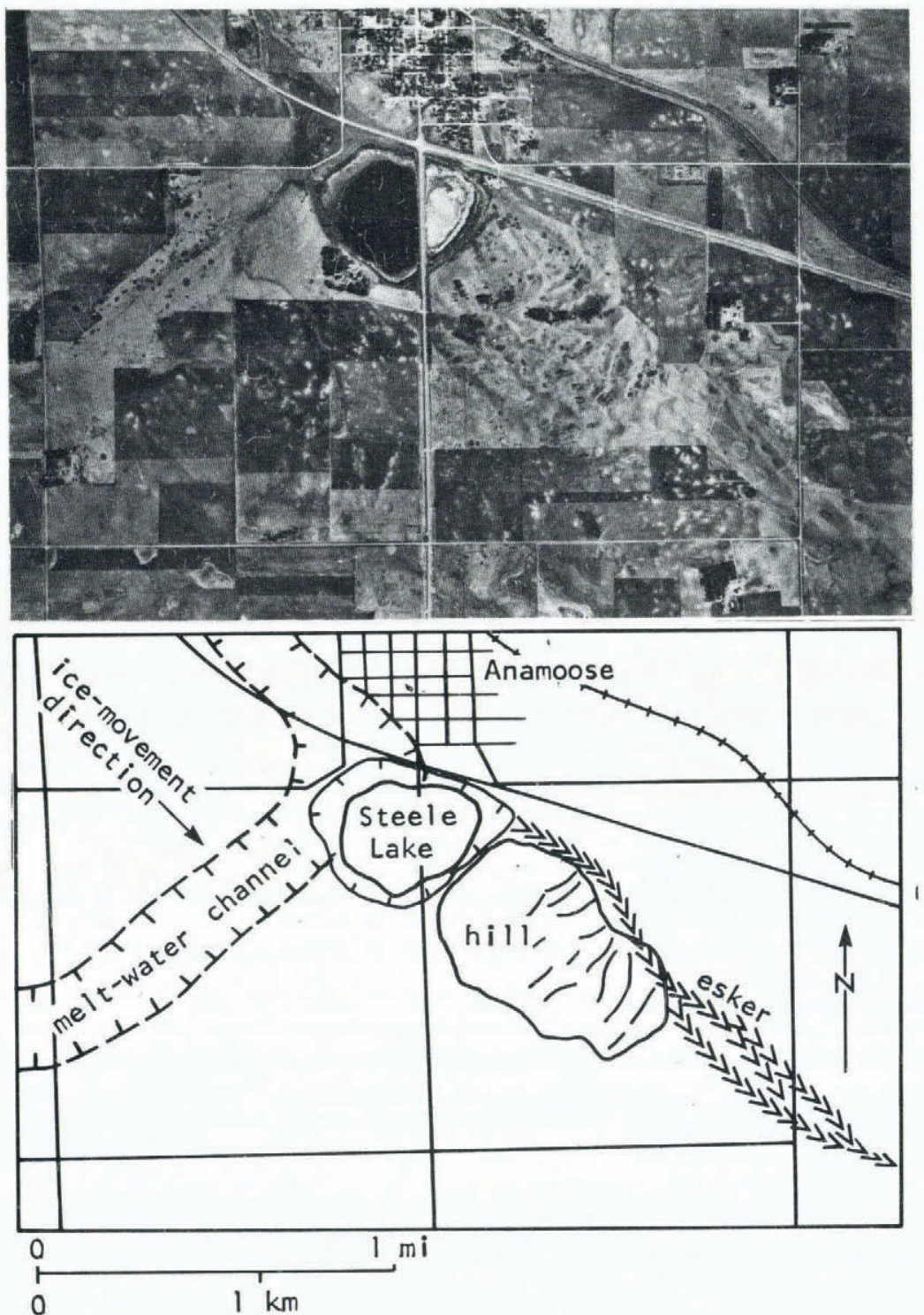

Fig. 2. Glacial-thrust hill and source depression at Anamoose, North Dakota (photograph: BA I-I BB-4, U.S. Department of Agriculture).

* In the explanations to Figures I and 4 the numbers following the colon (:) refer to sites shown on that figure. 
Glacial thrust masses, like tectonic thrust masses, have a variety of gradational manifestations (Moran, [ ${ }^{{ }^{1}}$ I97 I ] ). The simplest form consists of a hill or hills lying down-glacier from a depression of similar size and shape (Bluemle, I970; Clayton and Moran, [ ${ }^{\mathrm{c}}$ 1974], p. I04) (Fig. 2). In many places the thrust block has been broken into a series of imbricate slabs that appear as parallel ridges on the hill. In other places the hills consist of a series of imbricate thrust sheets or overturned folds that occur in arcuate groups, which are concave up-glacier (Fig. 3).

The related depression is normally partly filled with supraglacial mud-flow sediment in the form of hummocky subsidence terrain or lacustrine silt and clay. In some places the source depressions are as much as $2 \mathrm{~km}$ up-glacier from the hill. In other places no depression
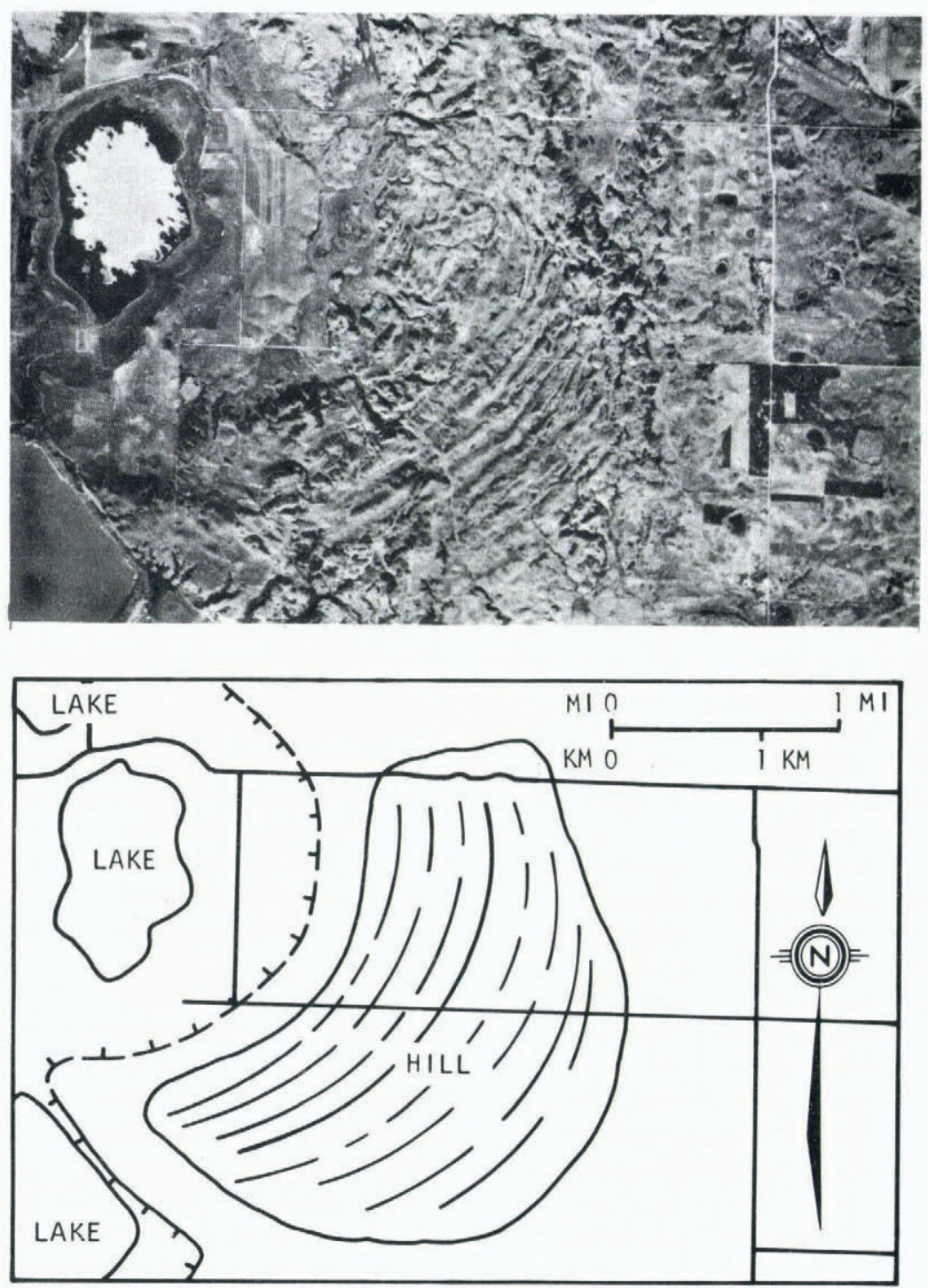

Fig. 3. Antelope Hills, arcuate glacial-thrust ridges il north-central North Dakota composed of imbricate slabs of Tertiary continental sediment. The hatchered line outlines the source depression (photograph: 340-69o9, II-8-52, Acro Service Corp.). 
is present, and in at least some places there is evidence that the thrust block was a hill on the pre-glacial surface and was simply moved to a new location. In other places, the existence of glacial thrust features is known only from study of the sub-surface (Stalker, 1975, 1976; Christiansen and Whitaker, [ $\left.{ }^{\mathrm{C}} \mathrm{I} 976\right]$; Sauer, 1977).

The material comprising thrust sheets and folds is highly variable. Older glacial sediment is perhaps the most common constituent. It is of least interest, however, because it lacks the bedding needed to reconstruct the structure of the mass. Many thrust masses are composed of pre-existing lake or river sediment of Quaternary age. The most interesting are those known to be composed of Cenozoic or Mesozoic marine or continental sediment (Slater, 1927; Kupsch, 1962). For example, Sibley Buttes in North Dakota (Fig. I: 28) consists of a ridge of Cretaceous marine sandstone about $2 \mathrm{~km}$ wide, with dozens of parallel sandstone hogbacks.

The internal structure of most thrust masses is known only from shallow road cuts and, in such cases, information is not available to distinguish between overturned folds and thrust sheets. Bedding that can be seen on air photographs on the down-glacier side of some individual thrust ridges on Sibley Buttes suggests that the ridges are the edges of thrust sheets dipping up-glacier. In contrast, Byers (1959) and Kupsch (I962) have concluded that many thrust masses in Saskatchewan and Alberta are overturned anticlines or thrust-faulted overturned anticlines. The depth of folding and thrusting is generally unknown but Kupsch (1962) suggested that the vertical extent of glacier-thrust deformation in Saskatchewan is between 60 and $180 \mathrm{~m}$. Moran ( $\left[{ }^{\mathrm{c}} \mathrm{I} 97 \mathrm{I}\right]$, unpublished) reported glacial deformation to a depth of about $200 \mathrm{~m}$ beneath Thunder Hill in eastern Saskatchewan.

\section{Streamlined terrain}

Glacial terrain is characterized by a wide variety of streamlined landforms that were formed by processes operating at or near the bed of vanished glaciers (Clayton and Moran, $\left[{ }^{c_{1}}{ }_{974}\right]$, I977). These features range in size from scratches or striations less than $\mathrm{I} \mathrm{mm}$ deep and several millimetres long to smoothed hills at least $200 \mathrm{~m}$ high and $20 \mathrm{~km}$ or more long. These features are characteristically smoothed and elongated in the direction of ice flow, as deduced from other evidence. Length-to-width ratios vary from as little as 2 to I to more than 250 to $\mathrm{r}$. Of the wide variety of terms applied to these features, "drumlin" and "fluting" are probably the most generally used.

In the western prairie areas of the United States and Canada, glacially streamlined forms generally are low and have large length-to-width ratios. Ridges in McHenry County, North Dakota (Fig. 4: 4I), for example, are generally $\mathrm{I}-5 \mathrm{~km}$ long, $45^{-60} \mathrm{~m}$ wide, and $2-5 \mathrm{~m}$ high. One especially well-developed ridge, Hogback Ridge, is over $20 \mathrm{~km}$ long, nearly roo $\mathrm{m}$ wide at the base, and decreases in height from 15 to $2 \mathrm{~m}$ along its trend. Similar dimensions characterize streamlined forms throughout North Dakota, Saskatchewan, and Alberta. In some areas in the prairies, shorter, higher features, which are more typical of classical drumlins, have been reported (Kupsch, 1955, p. 329) (Fig. 4:32).

Although streamlined terrain does not cover extensive areas in the prairies, its occurrence is widespread. Only $2 \%$ of the glaciated part of North Dakota, for instance, is occupied by such terrain (Clayton and Moran, 1977; Clayton, in press) but streamlined features are described from i I of 40 glaciated counties distributed throughout the state (Fig. 4: 37-48). Small areas of drumlins or flutes have been reported for Manitoba (Fig. 4: 35, 36), Saskatchewan (Fig. 4: 24-34, 49, 50), and Alberta (Fig. 4: 1-23).

Streamlined features in the prairies are variously composed of pebble-loam, gravel, sand, clay, silt, shale, siltstone, and sandstone (Fig. 4). Observations by the authors as well as others (e.g. personal communication from J. D. Mollard, I978) indicate that outcrops sufficiently deep to reveal the interior of streamlined features almost invariably expose granular material or deformed pre-existing rock or sediment. 


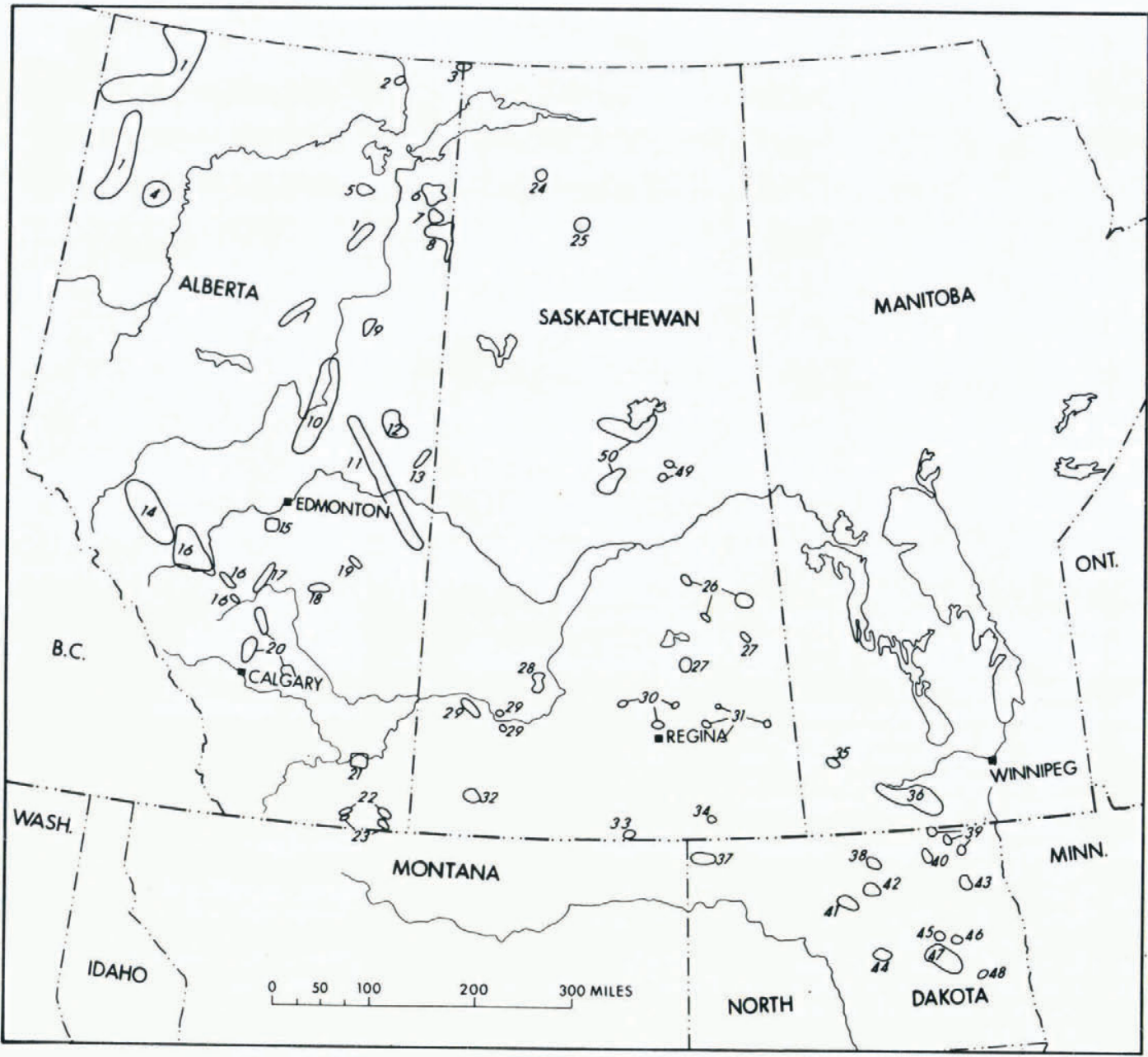

Fig. 4. Map showing distribution of glacially streamlined terrain in the prairie region of North America.

\section{Description}

I. Unknown

2. Low-relief flutings

3. Flutings grading into drumlins and flutings to the north-east; wavelength $80-240 \mathrm{~m}$

4. Flutings, wavelength $150 \mathrm{~m}$

5. Long shallow flutings; $>5 \mathrm{~km}$ long, $320 \mathrm{~m}$ wide and $1.5-9 \mathrm{~m}$ deep

6. Fluted and drumlinized outwash; fluting and drumlins grade into each other

7. Crag and tail

8. Fluted and drumlinized outwash

9. Fluting and drumlins

ro. Flutings; $\mathrm{L}=0.8-5 \mathrm{~km}, \mathrm{~W}={ }_{150-}$ $300 \mathrm{~m}, \mathrm{H}=2-\mathrm{r} 5 \mathrm{~m}$; frequently superimposed on hills

\section{Explanation to Figure 4}

Unknown

Unknown

Erosion of Precambrian granite and metamorphic rocks; all eroded to same depth

Unknown

Stony loam

Sand and gravel, boulders layer the top

Granite knob with sand and gravel lee side

Sand and gravel

Clayey pebble-loam (till)

Pebble-loam

\section{References}

Gravenor and Menley, I 958 Bayrock, I972[c]

Gravenor and Menley, $195^{8}$

Gravenor and Menley, 1958

Gravenor and Menley, I958; Mollard, [1975?]

Bayrock, 1972[b]

Bayrock, I97 I

Bayrock, r971

Bayrock and Reimchen, r 974

Examination of air photographs;

Shaw, 1975

continued overleaf 
Explanation to Figure 4-continued from previous page.

I 1. Flutings, gradational into drumlins in places; $\mathrm{L}$ up to $16 \mathrm{~km}, \mathrm{~W}=$ $60-120 \mathrm{~m}, \mathrm{H}=0.6-6 \mathrm{~m}$

12. Flutings associated with ice-thrusted hills

13. Fluting; $L<5 \mathrm{~km}, W=50 \mathrm{~m}$, $\mathrm{H}=2-3 \mathrm{~m}$

14. Fluting and drumlins; local relief up to $30 \mathrm{~m}$, generally $15 \mathrm{~m}$

15. Flutings, poorly developed

I6. Flutes

17. Flutings parallel; $\mathrm{H}<30 \mathrm{~m}$, wavelength $150 \mathrm{~m}$

18. Flutings; fan-like down-ice; $\mathrm{H}<30$ $\mathrm{m}$, wavelength $150 \mathrm{~m}$

19. Elongate

20. Flutings: $\mathrm{L}=1.5-5 \mathrm{~km}, \mathrm{~W}=30-$ $90 \mathrm{~m}, \mathrm{H}=\mathrm{I}-5 \mathrm{~m}$; drumlins : $\mathrm{L}=0.8-2.5 \mathrm{~km}, \mathrm{~W}=300-450$ $\mathrm{m}, \mathrm{H}=<\mathrm{I}_{5} \mathrm{~m}$; intermingled with each other

21. Flutings

22. Flutings; $\mathrm{L}>1.5 \mathrm{~km}, \mathrm{H}<2 \mathrm{~m}$

23. Drumlins; exceed $15 \mathrm{~m}$ in places

24. Drumlin; $\mathrm{L}=\mathrm{I} \mathrm{km}, \mathrm{W}=300 \mathrm{~m}$

25. Flutes or drumlinoids; $L=1 \mathrm{~km}$, $\mathrm{W}=100 \mathrm{~m}$

26. Drumlins; flutes $2-4 \mathrm{~m}$ relief

27. Flutings up to $3 \mathrm{~km}$ long, $60-90 \mathrm{~m}$ wide, generally $\mathrm{I}-2 \mathrm{~m}$ high but may be up to $8 \mathrm{~m}$; unobscured to buried by supraglacial mud-flow sediment

28. Flutings, closely spaced, elongate, low ridges

29. Flutes

3o. Flutings; as much as $1 \mathrm{I} \mathrm{km}$ long, $\mathrm{W}=60-90 \mathrm{~m}, \mathrm{H}=\mathrm{I}-3 \mathrm{~m}$

31. Flutings; $\mathrm{H}=6 \mathrm{~m}, 45 \mathrm{~m}$ apart

32. Drumlins; average of 98 is $\mathrm{L}=230$ $\mathrm{m}, \mathrm{W}=107 \mathrm{~m}, \mathrm{H}=23 \mathrm{~m}$ (up to $46 \mathrm{~m}$ )

33. "Streamlined eroded bedrock"

34. Flutes; $\mathrm{L}<\mathrm{r} .6 \mathrm{~km}, \mathrm{~W}=60 \mathrm{~m}$, $\mathrm{H}=0.6-1.5 \mathrm{~m}$

35. Drumlins, flutings, grooves; approximately $300 \mathrm{~m}$ long

36. Streamlined hills

37. Flutes

38. Flutes

39. Flutes and drumlins

40. Flutes

41. Flutings and drumlins; $L=1 \cdot 5^{-5}$ $\mathrm{km}$, maximum $20 \mathrm{~km}, \mathrm{~W}=45^{-}$ $60 \mathrm{~m}$, maximum $100 \mathrm{~m}, \mathrm{H}=2-5$ $\mathrm{m}$, maximum $15^{-20} \mathrm{~m}$

42. Flutes

43. Flutes

44. Flutes

45. Flutes

46. Flutes

47. Flutes

48. Flutes

49. Flutes; $\mathrm{H}=3-9 \mathrm{~m}$

50. Drumlins; $\mathrm{W}=1.6 \mathrm{~km}, \mathrm{H}=12 \mathrm{~m}$
Mainly pebble-loam, locally pebble-loam, sand, and gravel layers

Likely all pebble-loam

Pebble-loam, sand and shale

Pebble-loam, thin pebble-loam over bedrock, and bedrock

Pebble-loam and bedrock

Clayey and sandy pebble-loam

Mainly pebble-loam but some outwash or lacustrine sediment

Pebble-loam

Pebble-loam

Flutings bedrock or pebble-loam; drumlins usually pebble-loam

Unknown

Pebble-loam, pebble-loam on bedrock, or bedrock, depending on location

Outwash sand

Sand

Likely sandy pebble-loam

Likely sandy pebble-loam

Pebble-loam

Pebble-loam

Pebble-loam

Gravel and pebble-loam

Bedrock

Pebble-loam

Rock cored-brecciated shale

Pebble-loam $<3 \mathrm{~m}$ thick

Pebble-loam; core brecciated shale

Sand, thinly draped with pebbleloam

Shale

Pebble-loam $<3 \mathrm{~m}$ thick, over gravel

Pebble-loam $<3 \mathrm{~m}$ thick, over gravel

Pebble-loam
Fenton and Andriashek, 1978; Ellwood, unpublished

Fenton and Andriashek, 1978

Fenton and Andriashek, 1978

Gravenor and Menley, 1958; Roed, 1970

Bayrock, 1972[a]

Boydell and others, 1974

Gravenor and Menley, I958; Stalker, 1960

Gravenor and Menley, 1958; Stalker, 1960

Gravenor and Ellwood, 1957

Stalker, 1973

Berg and McPherson, 1972

Westgate, 1967

Westgate, 1967

Mollard, [ r 975 ?]

Mollard, [1975?]

Moran, unpublished

Scott, I97 I

David, unpublished

Christiansen, I96 I

Christiansen, 1960, 1972, 1973

Kupsch, 1955

Parizek, 1964

Christiansen, ${ }^{195} 6$

Elson, $195^{8}$

Halstead, I959

Clayton, in press

Deal, 1971

Clayton, in press

Arndt, I975; Hobbs, unpublished

Lemke, 1958, 1960; Clayton and Moran, [ $\left.{ }^{\mathrm{C}} \mathrm{1} 974\right]$

Clayton, in press

Clayton, in press

Clayton, in press

Aronow, 1959

Bluemle, I971

Clayton, in press

Kelly and Block, I 967

Langford, I 973

Langford, r973

$\mathrm{L}=$ length, $\mathrm{W}=$ width, $\mathrm{H}=$ height 
A variety of structural features has been described within the ridges of streamlined terrain. Systematic sets of joints have been reported from drumlins in Saskatchewan by Kupsch ( 1955 , p. 330-36). Two types of folds, broad open anticlinal folds and complexly overturned anticlines that in places form diapiric intrusions into overlying materials, have also been observed. In McHenry County, North Dakota, a road cut exposes nearly the entire thickness of a low streamlined ridge composed of a sequence of interbedded sand and silt capped by about $\mathrm{I} \mathrm{m}$ of pebble-loam. These materials are folded into a broad anticline, the limbs of which parallel the surface of the ridge itself. Whittecar and Mickelson (1977) reported clastic dikes and overturned folds within drumlins near Milwaukee, Wisconsin. The folds, which were as much as $30 \mathrm{~m}$ high, have axes that are parallel or oblique to the long axis of the drumlins and in some places are faulted and displaced beyond reconstruction (Whittecar and Mickelson, 1977, p. 2 16). The sediment in cores of many streamlined forms is broken by thrust faults (Whittecar and Mickelson, 1977). In North Dakota, the shale cores of drumlins, where they have been exposed, are generally brecciated.

A unique type of streamlined feature, which was termed a "murdlin" by Stalker (I973), was originally recognized in a small area north-east of Calgary, Alberta. Other examples have been found in north-central North Dakota. A murdlin consists of two parallel streamlined ridges that are seprated by a trough, which extends below the level of the surrounding plain. The down-glacier end of the trough is formed by a mound of debris that tails off on either side to form the lateral ridges. Murdlins as much as $2-3 \mathrm{~km}$ long occur in fields with other streamlined features. The appearance of a murdlin can best be visualized by dragging a finger through a substance such as cake frosting or peanut butter.

Evidence of thrusting associated with streamlined terrain is widespread throughout the prairies. In most areas of streamlined terrain, depressions lie immediately up-glacier from the streamlined ridges. In some places a depression is associated with each ridge, whereas in other places a large depression lies up-glacier from a broad area of fluted terrain. Where the internal structure of ridges is exposed, faulting, brecciation, and folding commonly indicate differential movement within the core of the ridge in the direction of ice flow (Moran and Whitaker, 1969; Moran, [ $\left.{ }^{\mathrm{C}} \mathrm{1} 97 \mathrm{I}\right]$, unpublished; Clayton, in press; Hobbs, unpublished; Fenton and Andriashek, in preparation). North of Calgary, Alberta, near the town of Balzac, a field of small thrust blocks has been extensively streamlined (Moran, in preparation) (Fig. $4:$ 10). Nearly all of the larger streamlined ridges lie immediately down-glacier of a depression. Displacements between individual thrust blocks indicate the presence of numerous strike-slip faults or fault zones along which differential movement has occurred. The streamlined thrust terrain consists largely of sandstone and siltstone draped by a thin veneer of lodgement till.

\section{PATterns of Distribution OF LANDForms OF THE GLACIER BED}

Although glacial-thrust terrain is present throughout the glaciated prairies, its distribution is far from uniform. Huge areas contain no evidence of thrusting whatsoever. This is in part a result of the absence of such features and in part a result of non-recognition of features that are present. As our understanding improves, previously unrecognized occurrences of glacialthrust terrain are being found. Throughout the prairies, glacial-thrust terrain is best developed on the up-slope edge of major uplands and along major ice-marginal positions that are identified by stratigraphic and morphologic evidence. In many cases, though by no means all, the thrust masses situated on the up-slope edge of uplands also lie along ice-marginal positions. Examples of thrust terrain along the up-glacier edge of major uplands include the main loops of the Streeter moraine and Martin moraine in North Dakota (Fig. I : 19, 20, 2 I, 23, 25-30) and most of the recognized thrust terrain in Saskatchewan (Fig. I : 12, I3, I4, I6-18). Examples of thrust terrain known to lie along former ice-marginal positions include 
most of the recognized thrust terrain in North Dakota (Fig. I : 19-30). We believe that most of the thrust terrain in Saskatchewan and Alberta is also situated along former ice-marginal positions, although existing evidence is inadequate to confirm this conclusion.

Glacial-thrust masses that lie more than about $5 \mathrm{~km}$ up-glacier from recognized icemarginal positions are known but they are generally smoothed and do not exhibit the characteristic transversely ridged appearance of those situated along former margins. Examples of these features include some of the hills in north-central North Dakota (Fig. I : 22 and others to the north-west; Fig. 4:40), east-central Saskatchewan (Fig. I : I 5, I2, and others north-west of 12), and southern Alberta (Fig. I: 10, I, 2, 4, 6, 7, 8).

The association of glacial-thrust terrain with buried aquifers, which was suggested by Moran $\left(\left[{ }^{c} I_{97} I\right]\right)$, is a commonly observed situation throughout the prairies. Because the detailed sub-surface data that are required to demonstrate this association are generally not available, we consider it probable that this occurrence is more common than can be proved at present. Examples of large thrust ridges overlying major buried aquifers in North Dakota include the Alkabo moraine (Fig. I : 19) and Prophets Mountain (Fig. I: 25), which overlie the pre-glacial valleys of the Missouri and Knife Rivers, respectively. Smaller thrust features overlie minor buried aquifers throughout North Dakota (Fig. 2, I : 22, 24).

In North Dakota, the subglacially streamlined terrain generally occurs up-glacier from the glacial-thrust terrain. Streamlined terrain nowhere extends to the outer limit of an advance but glacial-thrust terrain occurs along the limit of most advances. For example, a belt of thrust terrain $2-3 \mathrm{~km}$ wide occurs between the outer limit of the Heimdal-Cooperstown advance (Fig. I : 24) and the zone of streamlined terrain south-east of Devils Lake (Fig. 4:45;

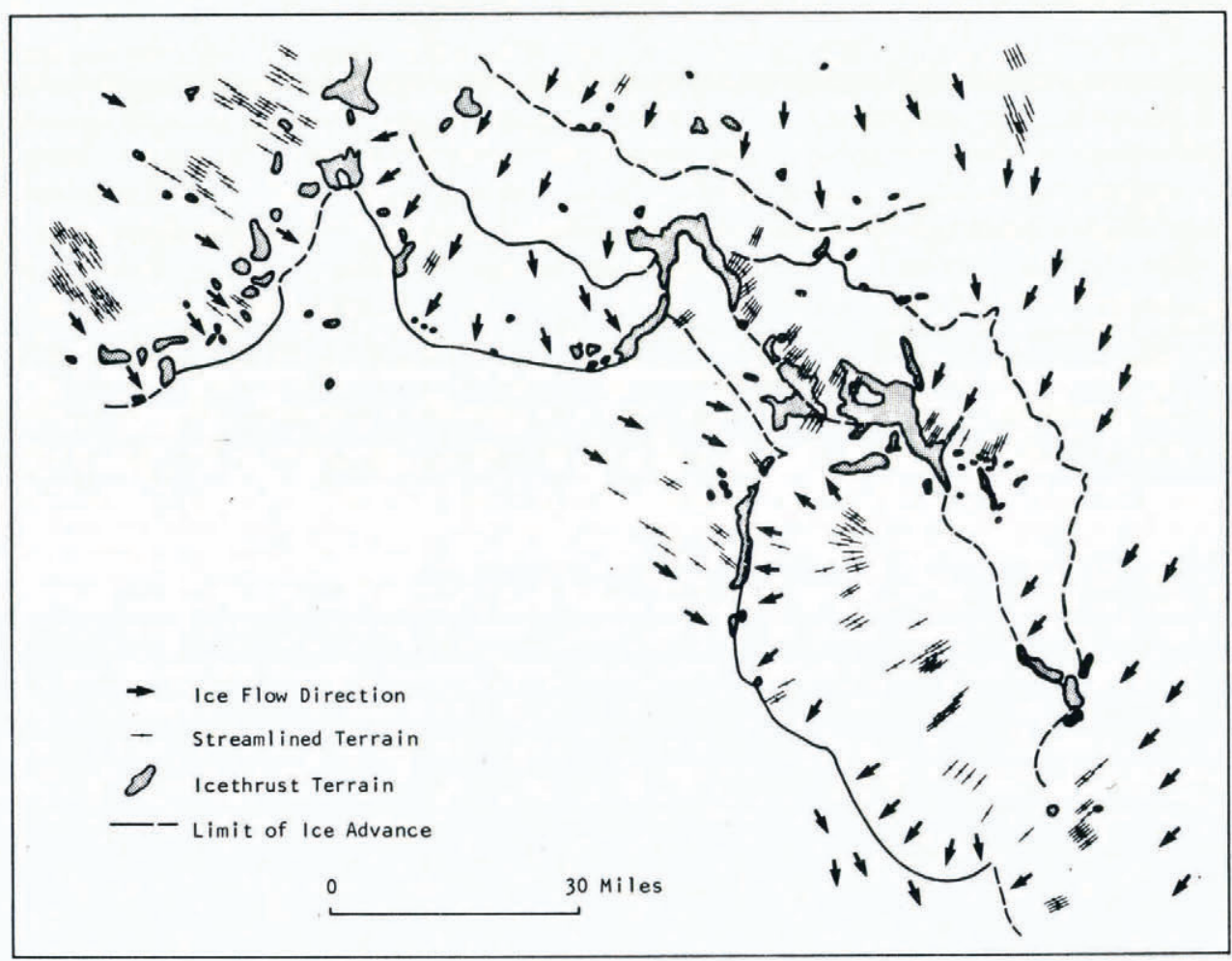

Fig. 5. Map showing relationship between ice-margin positions and large-scale landforms produced at the glacier bed in east-central North Dakota. 
Fig. 5). This pattern is repeated in numerous places in North Dakota (Fig. 5). In places, the terminal zone of thrusting is wider than $2-3 \mathrm{~km}$ but streamlined terrain extends to within $2-3 \mathrm{~km}$ of the former maximum ice-margin position, suggesting that the thrusting farther from the margin occurred during advance of the glacier. Near Calgary, Alberta, a similar zone of streamlined thrust terrain is separated from an ice margin by a $3-5 \mathrm{~km}$ wide zone of thrust terrain which has not been streamlined.

One additional landform relationship is worthy of note. In several places throughout the prairies, an esker originates in the depression up-glacier from a glacial-thrust block. South of Anamoose, North Dakota, for example, a small esker begins at the north-east corner of the lake that occupies the source depression for a thrust hill that lies immediately to the south-east (Fig. 2). The esker can be traced around the north-east side of the hill and then several kilometres farther to the south-east. A similar relationship occurs near Calgary, Alberta (Fig. I : 10).

\section{GENESIS OF LANDFORMS OF THE GLACIER BED}

On the basis of the characteristics and spatial distribution of glacial-thrust terrain and subglacially streamlined terrain, it is possible to draw some conclusions about the genesis of these two types of terrain. We conclude that thrust features were formed by plucking of large blocks of material from the bed where the advancing glacier was frozen to the substrate. The combination of a narrow frozen-bed zone along the margin of a glacier advancing up-slope appears to have provided the optimum conditions conducive to thrusting, especially where the glacier advanced over a buried aquifer. Subglacially streamlined terrain, on the other hand, is believed to have formed in areas where the glacier bed was at the melting point and therefore where movement at the bed was by sliding. Streamlined terrain is concluded to have formed by erosion of the substrate or by erosional moulding of thrust blocks accompanied by deposition of material in the lee of the block. Such deposition may have occurred both from the ice and by injection of plastically deforming substrate materials. We consider it likely that the formation of glacial-thrust terrain and at least the initial stages of formation of subglacially streamlined terrain occur under non-steady-state conditions of glacier-margin advance or down-glacier movement of the boundary between frozen-bed and thawed-bed zones. The remainder of this section is a discussion of the components of this model.

\section{Basal temperature}

Most thermal models of the continental glacier that covered North America during the Wisconsinan suggest an outer thawed-bed zone several hundred kilometres wide around much of the periphery (Hooke, 1977; Sugden, 1977). However, some models suggest the possibility of a narrow frozen-bed zone a few kilometres to a few tens of kilometres wide at the outermost limit of the ice sheet (Clayton and Moran, [ ${ }^{\mathrm{c}}$ 1974], 1977; Hooke, 1977; Sugden, 1977).

Up-glacier from this narrow frozen-bed zone, the models suggest that the bed of the glacier was at the pressure-melting point. It is generally accepted that glacial movement involved a significant component of basal sliding in areas of such thawed-bed conditions (Weertman, 1957, I964; Clayton and Moran, [ ${ }^{{ }^{1}}$ 974] ; Sugden, 1977). Where frozen-bed conditions exist, glacial movement occurs primarily by internal deformation of the ice, but shear failure in the substrate may also occur if stresses exceed the strength of the material.

Because of the importance of the thermal regime to the mechanism of formation of subglacial landforms, we have made some additional calculations to evaluate the glaciological conditions under which it might have existed. The computer program described by Hooke (r 977 ) was modified to include the depression of the melting point as a result of pressure at the bed. The 
program gives the steady-state temperature distribution along a flow line from the divide to a margin (Fig. 6). The boundary conditions and various constants used in the calculations are those given by Hooke ( 1977 , p. 6, I I-12), with the exception that the gradient required to remove the geothermal heat varies along the flow line, following Sugden (1977). The nonsteady-state conditions under which glacial-thrust terrain is believed to have formed probably do not deviate sufficiently from a steady state to invalidate the general conclusions.
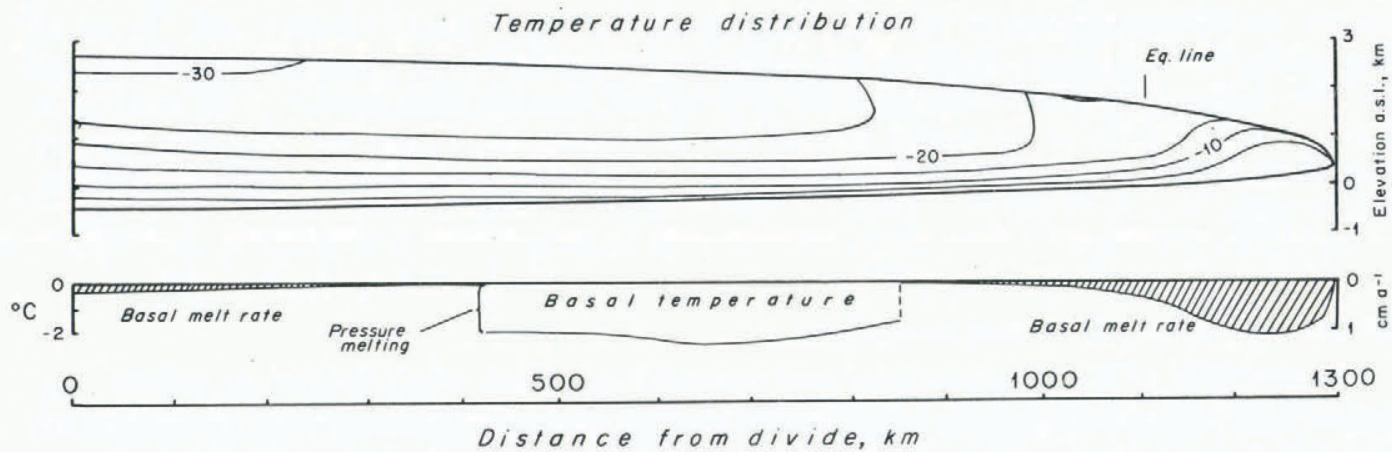

Fig. 6. Calculated temperature distribution in a glacier with a maximum accumulation rate of $20 \mathrm{~cm} /$ year and mean annual temperature at the margin of $-7 \cdot 5^{\circ} \mathrm{C}$. Basal temperature and melt rate (cross hatched) are shown at bottom.

The procedure used in the program for estimating the ice-sheet profile avoids arbitrary assumptions regarding the profile or basal shear stress. Instead, the primary independent variables that determine the profile - the accumulation pattern and the viscosity parametersare estimated. A limitation of the procedure, however, is that the dependence of the viscosity parameters on temperature and fabric is not included. The viscosity parameters used are based on measurements on the Barnes Ice Cap (Hooke, 1973[b]) and on study of the profile of the Greenland ice sheet (Lliboutry, ig68). These values are probably reasonable for situations in which basal temperatures are in the neighbourhood of $\mathrm{O}$ to $-5^{\circ} \mathrm{C}$ and a strong preferred orientation of crystals has developed. As our primary concern in the present context is with the outermost few kilometres of a I $300 \mathrm{~km}$ flow line, these uncertainties in the profile will not introduce appreciable error into the conclusions.

Two important assumptions in the column model equations (Budd and others, I97I) that were used for the temperature calculations should be discussed. The first is that the effect of longitudinal advection of heat can be approximated by assuming that the warming rate at depth is proportional to the surface warming rate as ice moves to lower latitudes and elevations. Budd and others (1971) assumed a constant of proportionality of I.o but Hooke (1977) found that this produced physically impossible results near the equilibrium line. Hooke arbitrarily used a value of 0.5 for most of his calculations and that value is used here. The effects of this assumption are appreciable in the lower part of the accumulation zone, where use of the lower constant of proportionality results in calculated basal temperatures that are as much as ro deg warmer (Hooke, 1977, fig. $4 \mathrm{~d}$; note that the labels on the two curves in this figure are switched). However, within a few kilometres of the margin this effect is probably negligible.

The second important assumption is that the magnitude of the vertical velocity decreases linearly with depth. This assumption results in calculated basal temperatures in the accumulation area that are probably a few degrees too cold (Philberth and Federer, 1971 ; Hooke, I 97.7, fig. 3). The magnitude of the error in the ablation area is unknown but it is probably not nearly as large. 
An additional assumption of the present model is that virtually all melt water produced by basal melting drains away from the bed into the substrate rather than flowing down-glacier along the bed and refreezing to the base in colder areas. Such refreezing could raise the temperature at the base of the glacier to the melting point in places where the present model calculates temperatures that are below freezing.

The approach used in the present modelling is to seek combinations of accumulation pattern and mean annual marginal temperature that result in sub-freezing temperatures in a $2 \mathrm{~km}$-wide zone along the margin. The accumulation rate is assumed to be greatest $65 \mathrm{~km}$ up-glacier from the equilibrium line. Farther up-glacier the rate decreases linearly from this maximum value to one-quarter of it at the divide. Down-glacier the accumulation rate decreases linearly from the equilibrium line to the margin and is adjusted to give a balanced mass budget.

Figure 7 gives curves of maximum accumulation rate versus mean annual temperature at the margin for three different equilibrium-line positions- 130,185 , and $260 \mathrm{~km}$ from the margin, respectively. A point on one of these curves represents a particular combination of maximum accumulation rate, mean annual temperature at the margin, and equilibrium-line position that will result in sub-freezing basal temperatures within $2 \mathrm{~km}$ of the margin and melting-point temperatures for some distance up-glacier from this $2 \mathrm{~km}$ position (Fig. 6). The net ablation rate at a point $2 \mathrm{~km}$ from the margin is given numerically at various points along the curves. This is the rate required for a balanced mass budget according to the assumed accumulation/ablation pattern described above. At the top of the figure the net ablation that might be expected for a given mean annual temperature is shown. These figures are based on measurements on the Barnes Ice Cap (Hooke, I973[a], 1976) and near Sondrestrømfjord, Greenland (Weidick, I968, p. 25), and are very approximate as they ignore many factors that have a substantial influence on ablation such as radiation balance, length of the melt season, and June snow depth. However, the pertinent observation is that

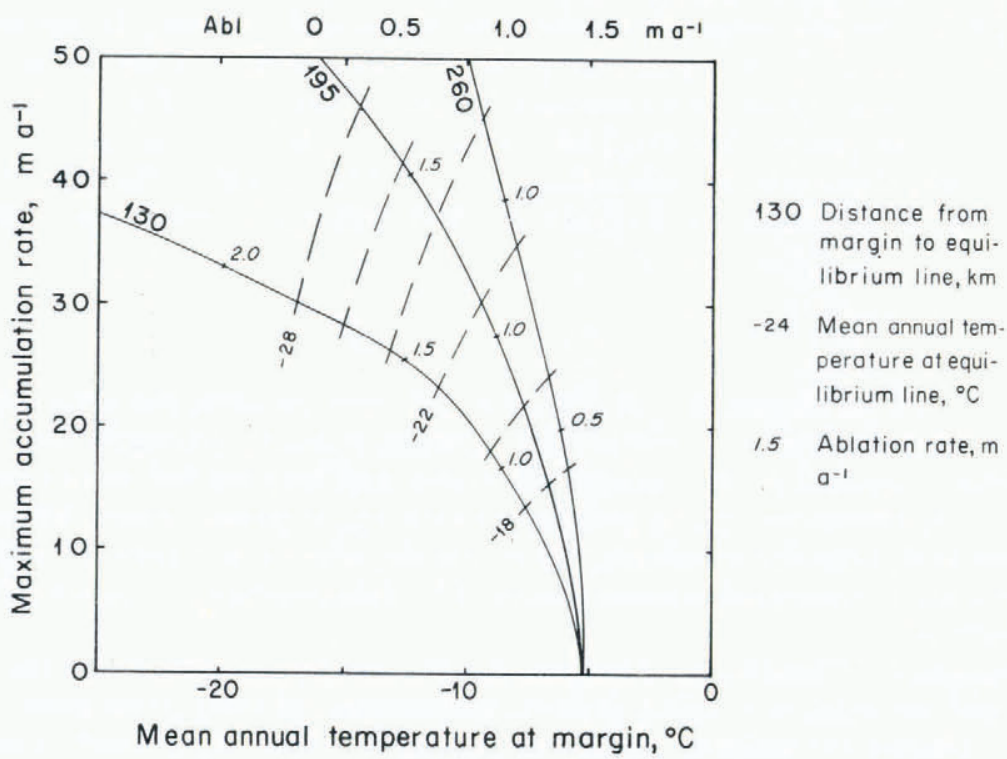

Fig. 7. Numerical model predicts basal temperatures that are below freezing within $2 \mathrm{~km}$ of margin for combinations of accumulation rate, marginal temperature, and equilibrium-line position shown by solid curves. Dashed curves show mean annual air temperature at equilibrium line; ice temperatures there will be somewhat warmer (Fig. 6) due to the effect of percolating melt water (Hooke, 1976). Ticks are deliberately omitted from ablation-rate scale at top due to uncertainty of figures. 
if the mean annual temperature at the margin were appreciately below $-10^{\circ} \mathrm{C}$, for example, ablation rates would probably be too low to result in a balanced mass budget. In other words the glacier would be advancing.

The mean annual temperature at the equilibrium line is shown by dashed lines crossing the curves in Figure 7. This temperature places a further constraint on allowable combinations of accumulation rate and marginal temperature, as summer conditions at the equilibrium line must be mild enough, on the average, to melt all of the snow-pack but none of the underlying ice. Mean annual equilibrium-line temperatures appreciably below $-15^{\circ} \mathrm{C}$ probably would not satisfy this condition. This appears to place a fairly severe restriction on the maximum accumulation rate, a restriction that we are reluctant to believe. Possibly the lapse-rate used in the calculations, $0.0 \mathrm{I} \mathrm{deg} / \mathrm{m}$, is too high but such a rate is certainly consistent with presentday lapse-rates in Antarctica (Budd and others, I97 I, p. 73) and Greenland (Mock and Weeks, 1966, p. 29 and 31 ). The only other factor used that would have an appreciable effect on the resulting equilibrium-line temperature is the position of the equilibrium line itself. But moving the equilibrium line to lower elevations, closer to the margin, reduces the size of the ablation area, thus requiring an increase in the ablation rate. This in turn requires higher upward vertical velocities and thus results in higher basal temperatures (Hooke, 1977, fig. 3A). However, if flow lines from the divide actually diverged more rapidly than radii of a circle (as is assumed in the model), this effect would be less serious.

In summary, despite the assumptions that enter into these calculations, three valid conclusions can probably be drawn from them. First, a frozen toe roughly $2 \mathrm{~km}$ wide could have existed at the margin of the Laurentide ice sheet in North Dakota. Thus this is a viable explanation for the observed thrust features. Farther north in Alberta, mean annual temperatures presumably were somewhat lower, resulting in a wider frozen toe, and this is consistent with an observed northward increase in the width of the marginal zone of thrust features. Secondly, for such a frozen toe to have existed in North Dakota, the mean annual temperature at the margin probably would have had to have been at least a couple of degrees less than $-5^{\circ} \mathrm{C}$ but not much less than $-10^{\circ} \mathrm{C}$. This is in agreement with pollen data (Wright, I976). Thirdly, accumulation rates were probably not very large; maximum rates substantially in excess of $0.3-0.4 \mathrm{~m} /$ year seem unlikely. This may be the first quantitative support for the common assumption that accumulation rates on the Laurentide ice sheet were comparable to those on the Greenland and Antarctic ice sheets today, and that these presentday ice sheets may thus be reasonable analogues for the Laurentide. Models tested using other viscosity and accumulation patterns do not give any reason to question the generality of these conclusions.

\section{Basal shear}

It is reasonable to suggest that as ice advanced over an area, the area experienced first frozen-bed conditions, and then, with further advance, thawed-bed conditions. Under frozenbed conditions, a vertical profile through the glacier and into the bed would normally consist of four zones: (I) debris-free ice, (2) debris-laden ice, (3) sediment or rock below the pressuremelting point and probably containing interstitial ice, and (4) sediment or rock that is free of ice but that is water saturated in some places. The debris-laden ice can contain interbedded layers of clean ice.

The penetration of continuous ice down into the substrate results in a firm bond between the glacier and the substrate, which permits transmission of shear stress from the moving ice to the bed. Glacial ice deforms readily at stresses of about $100 \mathrm{kN} / \mathrm{m}^{2}$ ( $\mathrm{r}$ bar) and has a fundamental strength (the stress required to initiate creep) appreciably less than this. The shear strength of all but the weakest of unconsolidated sediments is much larger. For example, glacial till in Montrail County, North Dakota, has shear strength values that range from 
$\mathrm{I} 35$ to $540 \mathrm{kN} / \mathrm{m}^{2}$ with a mean value of about $300 \mathrm{kN} / \mathrm{m}^{2}$ (Clayton, I972). Thus, where glacial ice is frozen to substrate material that has a shear strength significantly greater than the fundamental strength of ice, movement will normally occur by plastic flow within the ice.

The fact that glacial-thrust features do not occur everywhere but rather occur in only certain areas suggests that the shear strengths of sediment and rock are generally greater than the highest shear stresses that could be applied by the glacier. It is evident, however, that in those areas where glacial-thrust structures are found the shear strength of the substrate was exceeded.

Such failure could result from the substrate material having a low initial strength, possibly because of advantageously oriented planes of weakness, such as bedding planes or fractures, or from weakening of the substrate by a decrease in cohesion or effective normal stress.

Some unconsolidated sediment, especially clayey glacial lake sediment, has a very low shear strength. Sediment of glacial Lake Agassiz, for example, has shear-strength values that range from less than $25 \mathrm{kN} / \mathrm{m}^{2}$ to more than $65 \mathrm{kN} / \mathrm{m}^{2}$ (Moran, 1972 ; Arndt, 1977). Glaciallythrust lacustrine sediment is a common constituent of some ice-marginal disturbed complexes in eastern North Dakota (Bluemle, 1975). It is entirely possible that, in these cases, the inherent weakness of the substrate material itself permitted formation of the thrust structures without other factors being involved.

In many thrust structures in the prairies, semi-consolidated to thoroughly consolidated bedrock, which has quite high shear strength, has been deformed. Although failure of such materials may have resulted from pre-existing planes of weakness within the rock mass, analysis suggests that this is unlikely. Consider a glacier $100 \mathrm{~m}$ thick with a surface slope such that basal shear stress is $100 \mathrm{kN} / \mathrm{m}^{2}$ ( $\mathrm{r}$ bar). At a depth of $10 \mathrm{~m}$ in a substrate with a density of $2.04 \mathrm{I} \mathrm{Mg} / \mathrm{m}^{3}$, the shear stress will be about $100 \mathrm{kN} / \mathrm{m}^{2}$ and the normal stress will be about I $080 \mathrm{kN} / \mathrm{m}^{2}$. We use the shear-strength relation presented by Terzaghi and Peck ([ $\left.\left.{ }^{\mathrm{c}}{ }^{1967} 7\right]\right)$,

$$
s=c+(\mathcal{N}-h \gamma) \tan \phi
$$

where $s$ is the shear strength, $c$ is cohesion, $\mathcal{N}$ the normal stress, $h$ is the pressure head, $\gamma$ is the unit weight of water, and $\phi$ is the angle of internal friction. Taking the case of a dry cohesionless body of rock and using a friction term, $\tan \phi=0.5$, a very high value for rock, gives a shear strength $s$ of $540 \mathrm{kN} / \mathrm{m}^{2}$, about 4.5 times the applied shear stress. Thus, the fundamental strength of the ice is so much lower than the shear strength of the substrate that ice-surface slope and thickness never build up to the point of causing failure in the substrate.

However, the shear strength of the substrate can be substantially reduced if the pressure head is large. In the example above, if the pressure head is $100 \mathrm{~m}$ above the failure plane, Io $\mathrm{m}$ below the surface of the glacier, the shear strength is reduced to $50 \mathrm{kN} / \mathrm{m}^{2}$. The role of pore-water pressure in controlling shear strength has been well known in soil mechanics for many years (Terzaghi and Peck, $\left[{ }^{\mathrm{c}} \mathrm{I} 967\right]$ ). Its role in tectonic faulting was discussed by Hubbert and Rubey (1959) and its role in glacial thrusting was discussed by Moran ([ $\left.{ }^{\mathrm{C}} \mathrm{I} 97 \mathrm{I}\right]$, unpublished), Clayton and Moran ([ $\left.{ }^{\mathrm{c}} \mathrm{I} 974\right]$, 1977), Christiansen and Whitaker ([ $\left.{ }^{\mathrm{c}} \mathrm{I}_{976}\right]$ ), Bluemle (1970), and others.

The necessity for the reduction of shearing resistance in most bed materials in order for thrusting to occur, combined with the common coincidence of glacial-thrust features with buried aquifers, strongly suggests that elevated pore-water pressures played a major role in the genesis of glacial-thrust terrain.

\section{Origin of subglacial landforms}

By combining the preceding thermal model and mechanical principles, we can construct the following model of the genesis of landforms beneath an advancing Pleistocene glacier in the prairie region. Where the basal water was free to drain from the substrate through a conduit such as a buried valley fill, it moved under a gradient of decreasing potential toward the 
margin of the glacier. Where the aquifer was sealed at the margin as a result of a stratigraphic pinch-out, burial of the aquifer by glacial ice, or the development of thick permafrost in front of the glacier, the elevated pressure at some distance back under the glacier was transmitted, only slightly diminished, to the marginal zone. Where this elevated pressure was high enough, shear failure occurred in the substrate and blocks from the substrate moved along with the ice.

As the glacier continued its advance over the area, some of the blocks that were sheared from the bed were carried down-glacier. Other blocks remained near the base and were deposited immediately down-glacier of their source. Deposition occurred as a result of an encounter with still frozen-bed conditions, which allowed the block to again refreeze to the substrate, or as a result of a reduction in pressure head, which increased the shear resistance along the failure plane. The importance of compressive-flow conditions in the ice in lifting blocks above the bed has been stressed by Christiansen and Whitaker ( $\left.\left[{ }^{\mathrm{c}}{ }_{97} 6\right]\right)$. A complete gradation exists from blocks that were moved as little as $100 \mathrm{~m}$ and remained essentially intact to blocks that were moved many kilometres and, in many places, were thoroughly fragmented.

Where the glacier reached its furthest advance near the site of thrusting, the blocks were deposited within the frozen-bed zone and have been preserved more or less unmodified. Where deposition of blocks occurred more than about $2 \mathrm{~km}$ up-glacier from the final limit of the glacial advance, however, the frozen-bed zone moved on past the blocks and the thawed-bed zone migrated over the blocks. As the contact between glacier and the substrate thawed, the bond between them decreased until basal sliding began.

The proximal edge of the frozen-bed zone was probably irregular in most places. Variations in thickness of ice within the substrate that resulted from original irregularities in depth of ice penetration as well as differences in the rate of melting became more pronounced as the thickness of the frozen zone decreased until the zone became discontinuous. The disintegration of the frozen-bed zone undoubtedly began with the complete thawing of isolated areas of this ground ice. Closer to the thawed-bed zone, coalescence of some of these thawed areas formed continuous extensions of the thawed-bed zone into the frozen-bed zone. Finally, still farther up-glacier, isolated patches of frozen substrate surrounded by thawed-bed conditions marked the last remnants of originally thick or slowly melting ground ice.

Within this transition zone a variety of mixed and composite landforms was generated. Numerous, small thrust blocks were formed where frozen-bed conditions continued. Streamlined thrust blocks were developed where sliding conditions replaced frozen-bed conditions. Differential shear transverse to glacier movement, possibly as a result of frozen-bed conditions adjacent to thawed-bed and sliding conditions produced strike-slip faulting within thrust blocks. Murdlins formed where a small remnant of frozen substrate broke loose and was dragged down-glacier plowing up the highly saturated, soft thawed substrate on either side.

Formation of landforms within the thawed-bed zone appears to occur by two principal processes: (I) erosion of the substrate and (2) emplacement of thrust masses followed by erosional and depositional smoothing. In both processes the streamlined form is the result of abrasive erosion caused by sliding of the over-riding glacier.

Erosion of pre-existing substrate material is the most likely explanation for streamlined forms that contain fluvial or lacustrine sediment with undisturbed or slightly disturbed bedding or stratigraphic sequences consisting of several distinctly different layers of glacial sediment separated by fluvial sediment.

Most streamlined forms, however, appear to have formed by a composite process of erosion and deposition. In most streamlined terrain, the presence of evident source depressions up-glacier from the streamlined ridges, combined, in some places, with exposures that reveal structural deformation, strongly suggests that glacial thrusting in the frozen-bed zone played an integral part in their formation. Evidently, the glacial-thrust blocks provided obstructions around which the ice was required to deform. As the ice converged again around the thrust- 
block obstruction, debris in transit in the basal zone of the glacier was deposited in the form of a lee-side tail. Because of the converging and rising flow created in the basal zone of the ice by the obstruction, pebbles were deposited with the "herringbone" fabric that has been reported from these streamlined features (Gravenor and Menley, 1958; Shaw, 1975; Evenson, $\left[{ }^{\mathrm{c}}{ }_{\mathrm{I}}\right.$ 97 I $]$ ). Continued erosion of the generally unconsolidated block at the head of the feature and deposition of till in its lee led to the streamlined form of the feature.

A second mechanism by which debris can be deposited in the lee of thrust blocks is suggested by the evidence from eastern Wisconsin presented by Whittecar and Mickelson (1977). Here a significant part of some drumlins consists of deformed substrate material that has been injected upward into the drumlins. Although evidence for this type of process is scarce in streamlined landforms in the prairies, it may be important in some places. A zone of low pressure is created in the lee of obstructions on the glacier bed. Where the substrate is thawed, saturated, and highly plastic, substrate material can flow into this low-pressure zone in response to the load of the adjacent glacier. Continued movement of the glacier streamlines the form.

\section{Summary}

The two major types of landforms formed through interactions between the glacial ice and the substrate at the bed of Pleistocene ice sheets in the prairie regions of North America are glacial-thrust terrain and streamlined terrain.

Glacial-thrust terrain, which is concentrated along the margins of ice advances, over buried aquifers, and on the up-slope edges of uplands, formed in a marginal frozen-bed zone that in places was no more than $2 \mathrm{~km}$ wide. Conditions favourable for glacial thrusting include a frozen bed, pre-existing planes of weakness (such as bedding or jointing in sound rock or sediment), and decreased shear strength in rock or sediment (as a result of locally elevated pore-water pressure).

Streamlined terrain extends to the up-glacier edge of a zone of unstreamlined thrust blocks concentrated along the margins of ice advances. In many places the distal margin of the zone of streamlined terrain consists of a mixture of both streamlined and unstreamlined thrust blocks. Further up-glacier, the thrust blocks are more thoroughly streamlined, and unstreamlined blocks are rarely, if ever, present. Streamlined terrain formed where the glacier was sliding over its bed. Some streamlined terrain is largely erosional such as in the floors of thrust-block source depressions and in extensive areas of over-ridden fluvial sediment. In most places, however, the evidence strongly suggests that streamlined terrain results where thrust blocks form protuberances up from the bed into the ice. Glacier sliding and flow around these obstructions streamlined them by erosion of the blocks and deposition of till in the lee of the block.

\section{Acknowledgements}

Support for the temperature calculations was provided by the U.S. National Science Foundation (Grant EAR77-2 1098 ) to the University of Minnesota.

MS. received 20 September 1978 and in revised form 3 May 1979

\section{REFERENGES}

Andriashek, L. D., and others. 1979. Surficial geology, Wabamun Lake, Alberta, [by] L. D. Andriashek, M. M. Fenton, J. D. Root. Alberta. Research Council. [Map], NTS $8{ }_{3}$ G. [Scale 1 : 250 ooo.]

Arndt, B. M. 1975. Geology of Cavalier and Pembina Counties. North Dakota. Geological Survey. Bulletin 62, Pt. I. (North Dakota. State Water Commission. County Ground Water Studies, 20, Pt. I.)

Arndt, B. M. 1977. Stratigraphy of offshore sediment, Lake Agassiz, North Dakota. North Dakota. Geological Survey. Report of Investigation No. 60. 
Aronow, S. 1959. Drumlins and related streamline features in the Warwick-Tokio area, North Dakota. American Fournal of Science, Vol. 257, No. 3, p. 191-203.

Bayrock, L. A. 1971. Surficial geology, Bitumount. Alberta. Research Council. Map 34, NTS 74E. [Scale I : 250 00o.]

Bayrock, L. A. 1972[a]. Surficial geology, Edmonton. Alberta. Research Council. [Map], NTS 83H. [Scale I : 250 000.]

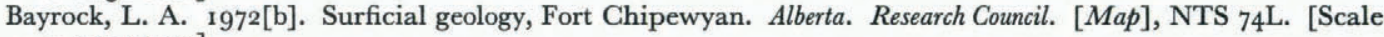
1 : 250 ooo.]

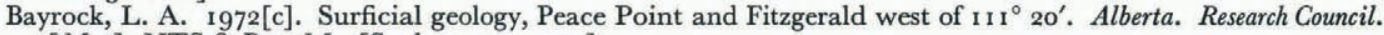
[Map], NTS $84 \mathrm{P}, 74 \mathrm{M}$. [Scale $1: 250$ ooo.]

Bayrock, L. A., and Reimchen, T. H. F. I974. Surficial geology, Waterways. Alberta. Research Council. [Map], NTS 74D. [Scale $1: 250$ ooo.]

Berg, T. E., and McPherson, R. A. 1972. Surficial geology, Medicine Hat. Alberta. Research Council. [Map], NTS 72 L. [Scale 1 : 250 ooo.]

Bluemle, J. P. 1965 . Geology and ground water resources of Eddy and Foster Counties, North Dakota. Pt. I . Geology. North Dakota. Geological Survey. Bulletin 44. (North Dakota. State Water Commission. County Ground Water Studies, 5.)

Bluemle, J. P. 1970. Anomalous hills and associated depressions in central North Dakota. Geological Society of America. Abstracts with Programs, Vol. 2, No. 5, p. 325-26.

Bluemle, J. P. 1971. Geology of McLean County, North Dakota. North Dakota. Geological Survey. Bulletin 6o, Pt. I. (North Dakota. State Water Commission. County Ground Water Studies, I9, Pt. I.)

Bluemle, J. P. 1973. Geology of Nelson and Walsh Counties, North Dakota. North Dakota. Geological Survey. Bulletin 57, Pt. I. (North Dakota. State Water Commission. County Ground Water Studies, I7, Pt. I.)

Bluemle, J. P. 1975. Geology of Griggs and Steele Counties. North Dakota. Geological Survey. Bulletin 64, Pt. I. (North Dakota. State Water Commission. County Ground Water Studies, 21, Pt. I.)

Bluemle, J. P., and others. 1967. Geology and ground water resources of Wells County. Pt. I. Geology, by J. P. Bluemle, G. A. Faigle, R. J. Kresl, and J. R. Reid. North Dakota. Geological Survey. Bulletin 51 . (North Dakota. State Water Commission. County Ground Water Studies, 12.)

Boydell, A. N., and others. 1974. Surficial geology, Rocky Mountain House, by A. N. Boydell, L. A. Bayrock, and T. H. F. Reimchen. Alberta. Research Council. [Map], NTS 83 B. [Scale I : 250 000.]

Budd, W. F., and others. 1971. Derived physical characteristics of the Antarctic ice sheet, by W. F. Budd, D. Jenssen, and U. Radok. ANARE Interim Reports. Ser. A(IV). Glaciology. Publication No. 120.

Byers, A. R. 1959. Deformation of the Whitemud and Eastend Formations near Claybank, Saskatchewan. Transactions of the Royal Society of Canada, Sect. 4, Vol. 53, Ser. 3, p. I-I I.

Carlson, C. G., and Freers, T. F. 1975. Geology of Benson and Pierce Counties, North Dakota. North Dakota. Geological Survey. Bulletin 59, Pt. I. (North Dakota. State Water Commission. County Ground Water Studies, 18, Pt. 1.)

Christiansen, E. A. 1956. Glacial geology of the Moose Mountain area, Saskatchewan. Saskatchewan. Dept. of Mineral Resources. Report DMR 21.

Christiansen, E. A. 1959. Glacial geology of the Swift Current area, Saskatchewan. Saskatchewan. Dept. of Mineral Resources. Report DMR 32.

Christiansen, E. A. 1960. Geology and groundwater resources, Qu'Appelle area, Saskatchewan. Saskatchewan. Research Council. Geology Division. Report SRC I.

Christiansen, E. A. 1961. Geology and groundwater resources, Regina area, Saskatchewan. Saskatchewan. Research Council. Geology Division. Report SRC 2.

Christiansen, E. A. 1965 . Geology and groundwater resources of the Kindersley area, Saskatchewan. Saskatchewan. Research Council. Geology Division. Report SRC 7.

Christiansen, E. A. 1972. Southern Saskatchewan. International Geological Congress, twenty-fourth session, Canada, 1972, Field excursion C-22, p. 24-36.

Christiansen, E. A. 1973. Quaternary geology and its application to engineering practice in the SaskatoonRegina-Watrous area, Saskatchewan. Geological Association of Canada. Guidebook, field trip C.

Christiansen, E. A., and Whitaker, S. H. 1973. Geology and groundwater resources of the St Walburg area, 73-F. Saskatchewan. Research Council. Map No. 18. [Scale I : 250000.$]$

Christiansen, E. A., and Whitaker, S. H. [ $\left.{ }^{\mathrm{c}} \mathrm{r} 976.\right]$ Glacial thrusting of drift and bedrock. (In Legget, R. F., ed, Glacial till. An interdisciplinary study. [Ottawa], Royal Society of Canada in co-operation with the National Research Council of Canada, p. 12 1-30. (Royal Society of Canada Special Publications, No. 12.)

Clayton, L. 1962. Glacial geology of Logan and McIntosh Counties, North Dakota. North Dakota. Geological Survey. Bulletin 37.

Clayton, L. 1972. Geology of Mountrail County, North Dakota. North Dakota. Geological Survey. Bulletin No. 55-IV. (North Dakota. State Water Commission. County Ground Water Study I4-IV.)

Clayton, L. In press. Geologic map of North Dakota. U.S. Geological Survey.

Clayton, L., and Freers, T. F. 1967. Roadlog. North Dakota. Geological Survey. Miscellaneous Series 30, Pt. I.

Clayton, L., and Moran, S. R. [' ${ }^{\mathrm{I}}$ 974.] A glacial process-form model. (In Coates, D. R., ed. Glacial geomorphology. Binghamton, State University of New York, p. 89-119. (Publications in Geomorphology.))

Clayton, L., and Moran, S. R. 1977. Thrust moraine on the interior plains of North America. (In Clayton, K., ed. X INQUA Congress, Birmingham, 1977. Abstracts. [Birmingham], INQUA, p. 87.)

David, P. P. Unpublished. Surficial geology and groundwater of the Prelate area. [Ph.D. thesis, McGill University, 1964.$]$

Deal, D. E. I971. Geology of Rolette County, North Dakota. North Dakota. Geological Survey. Bulletin 58. 
Denny, C. S., and others. 1968. A descriptive catalog of selected aerial photographs of geologic features in the United States, by C. S. Denny, C. R. Warren, D. H. Dow, and W. J. Dale. U.S. Geological Survey. Professional
Paper 59o. Ellwood, R. B. Unpublished. Surficial geology of the Vermilion area, Alberta. [Ph.D. thesis, University of
Illinois, I961.]

Elson, J. A. 1958. Pleistocene history of southwestern Manitoba. North Dakota. Geological Survey. Miscellaneous Series 10, p. 62-73.

Evenson, E. B. [ ${ }^{{ }}{ }_{1} 97$ r.] The relationships of macro- and microfabric of till and the genesis of glacial landforms in Jefferson County, Wisconsin. (In Goldthwait, R. P., ed. Till: a symposium. [Columbus], Ohio, Ohio State University Press, p. $345-64$.)

Feldman, R. M. 1964. Preliminary investigation of the paleontology and structure of Sibley Buttes, central North Dakota. Compass, Vol. 4I, No. 2, p. 129-35.

Fenton, M. M., and Andriashek, L. D. 1978. Glaciotectonic features in the Sand River area, northeastern Alberta, Canada. American Quaternary Association. Abstracts of the fifth Biennial Meeting, September 2-4, 1978, University of Alberta, Edmonton, Alberta, p. 199.

Gravenor, C. P., and Bayrock, L. A. 1955. Glacial geology of the Coronation district. Alberta. Research Council. Preliminary Report 55-1.

Gravenor, C. P., and Ellwood, R. B. 1957. Glacial geology, Sedgewick district, Alberta. Alberta. Research Council. Preliminary Report 57-1.

Gravenor, C. P., and Menley, W. A. 1958. Glacial flutings in central and northern Alberta. American fournal of Science, Vol. 256, No. 10, p. 715-28.

Gravenor, C. P., and others. I96o. Air photographs of Alberta, by C. P. Gravenor, R. Green, and J. D. Godfrey. Alberta. Research Council. Bulletin 5 .

Green, R. 1972. Geological map of Alberta. Alberta. Research Council. Map 35. [Scale: I : I 267000.$]$

Halstead, E. C. 1959. Ground-water resources of the Brandon map-area, Manitoba. Canada. Geological Survey. Memoir 300.

Hansen, D. E. 1967. Geology and ground water resources of Divide County, North Dakota. Pt. I. Geology. North Dakota. Geological Survey. Bulletin 45. (North Dakota. State Water Commission. County Ground Water
Studies, 6.)

Hobbs, H. Unpublished. Glacial stratigraphy of northeastern North Dakota. [Ph.D. thesis, University of North Dakota, 1975.]

Hooke, R. L. I973[a]. Flow in the margin of the Barnes Ice Cap and the development of ice-cored moraines. Geological Society of America. Bulletin, Vol. 84, No. 12, p. 3929-48.

Hooke, R. L. 1973[b]. Structure and flow in the margin of the Barnes Ice Cap, Baffin Island, N.W.T., Canada. Fournal of Glaciology, Vol. I2, No. 66, p. 423-38.

Hooke, R. L. 1976. Near-surface temperatures in the superimposed ice zone and lower part of the soaked zone of polar ice sheets. Fournal of Glaciology, Vol. 16 , No. 74, p. 302-04.

Hooke, R. L. 1977. Basal temperatures in polar ice sheets: a qualitative review. Quaternary Research, Vol. 7, No. I, p. I-13.

Hubbert, M. K., and Rubey, W. W. 1959. Role of fluid pressure in mechanics of overthrust faulting, I. Mechanics of fluid-filled porous solids and its application to overthrust faulting. Bulletin of the Geological Society of America,
Vol. 70, No. 2, p. $\mathrm{I}_{5} 5^{-205}$.

Kelly, T. E., and Block, D. A. 1967. Geology and ground water resources, Barnes County, North Dakota. Pt. I. Geology. North Dakota. Geological Survey. Bulletin 43. (North Dakota. State Water Commission. County Ground Water Studies, 4.)

Kupsch, W. O. r955. Drumlins with jointed boulders near Dollard, Saskatchewan. Bulletin of the Geological Society of America, Vol. 66, No. 3, p. 327-37.

Kupsch, W. O. 1962. Ice-thrust ridges in western Canada. Journal of Geology, Vol. 7o, No. 5, p. 582-94.

Langford, F. F. 1973. The geology of the Wapawekka area, Saskatchewan. Saskatchewan. Dept. of Mineral Resources. Report DMR 147. Lemke, R. W. ${ }^{1958 . ~ N a r r o w ~ l i n e a r ~ d r u m l i n s ~ n e a r ~ V e l v a, ~ N o r t h ~ D a k o t a . ~ A m e r i c a n ~ J o u r n a l ~ o f ~ S c i e n c e, ~ V o l . ~} 256$,
No. 4, p. $270-83$.

Lemke, R. W. 1960. Geology of the Souris River area, North Dakota. U.S. Geological Survey. Professional Paper 325.

Lliboutry, L. A. 1968. Steady-state temperatures at the bottom of ice sheets and computation of the bottom ice flow law from the surface profile. Fournal of Glaciology, Vol. 7, No. 51, p. $363-76$.

Mock, S. J., and Weeks, W. F. 1966. The distribution of 10 meter snow temperatures on the Greenland ice sheet. Fournal of Glaciology, Vol. 6, No. 43, p. 23-41.

Mollard, J. D. [1975?] Landforms and surface materials of Canada. Regina, Saskatchewan, J. D. Mollard.

Moran, S. R. [' ${ }^{1}$ g7I.] Glaciotectonic structures in drift. (In Goldthwait, R. P., ed. Till: a symposium. [Columbus], Ohio, Ohio State University Press, p. 127-48.)

Moran, S. R. 1972. Subsurface geology and foundation conditions in Grand Forks, North Dakota. North Dakota. Geological Survey. Miscellaneous Series 44.

Moran, S. R. Unpublished. Geology of the Hudson Bay area, Saskatchewan. [Ph.D. thesis, University of Illinois, 1969 .

Moran, S. R., and Whitaker, S. H. 1969. Geology and groundwater resources of the Hudson Bay area, 63-C. Saskatchewan. Research Council. Map No. 8. [Scale I : 250 ooo.] Parizek, R. R. 1964. Geology of the Willow Bunch area, Saskatchewan. Saskatchewan. Research Council. Report
SRC 4.

Philberth, K., and Federer, B. 1971. On the temperature profile and the age profile in the central part of cold ice sheets. Fournal of Glaciology, Vol. 10, No. 58, p. 3-14. 
Rau, J. L., and others. 1962. Geology and ground-water resources of Kidder County, North Dakota. Pt. I. Geology, by J. L. Rau, W. E. Bakken, J. Chmelik, and B. J. Williams. North Dakota. Geological Survey. Bulletin 36. (North Dakota. State Water Commission. County Ground Water Studies, 1.)

Roed, M. A. 1970. Surficial geology, Edson. Alberta. Research Council. Map 33, NTS 83F. [Scale I : 250 ooo.] St-Onge, D. A. 1967. Lancer, Saskatchewan, geomorphology. Canada. Dept. of Energy, Mines and Resources. Geographical Branch. [Map, scale I : 50 ooo.]

Sauer, E. K. 1977. The engineering significance of glacier ice-thrusting. 3oth Canadian Geotechnical Conference, 5-8 October 1977, Bessborough Hotel, Saskatoon, Sask., p. I-I 5-I-53.

Scott, J. S. 1971. Surficial geology of the Rosetown map-area, Saskatchewan. Canada. Geological Survey. Bulletin 190.

Shaw, J. 1975. The formation of glacial flutings. (In Suggate, R. P., and Cresswell, M. M., ed. Quaternary studies. Selected papers from IX INQUA Congress, Christchurch, New Zealand, 2-1o December 1973. Wellington, Royal Society of New Zealand, p. 253-58. (Royal Society of New Zealand. Bulletin 13.))

Slater, G. 1927. Structure of the Mud Buttes and Tit Hills in Alberta. Bulletin of the Geological Society of America, Vol. 38, No. 4, p. $721-30$.

Stalker, A. M. I96o. Surficial geology of the Red Deer-Stettler map-area, Alberta. Canada. Geological Survey.

Memoir 3o6.
Stalker, A. M. 1973. Surficial geology of the Drumheller area, Alberta. Canada. Geological Survey. Memoir 370.

Stalker, A. M. 1975. The large interdrift bedrock blocks of the Canadian prairies. Canada. Geological Survey. Paper 75-1A, p. 42 I-22.

Stalker, A. M. 1976. Megablocks, or the enormous erratics of the Albertan prairies. Canada. Geological Survey. Paper 76-1 C, p. 185-88.

Sugden, D. E. 1977. Reconstruction of the morphology, dynamics, and thermal characteristics of the Laurentide ice sheet at its maximum. Arctic and Alpine Research, Vol. 9, No. I, p. 2 I-47.

Terzaghi, K., and Peck, R. B. [ ${ }^{\mathrm{c}} \mathrm{I}_{967 .]}$ Soil mechanics in engineering practice. Second edition. New York, John Wiley and Sons, Inc.

Weertman, J. 1957. On the sliding of glaciers. Fournal of Glaciology, Vol. 3, No. 21, p. 33-38.

Weertman, J. 1964. The theory of glacier sliding. Fournal of Glaciology, Vol. 5, No. 39, p. 287-303.

Weidick, A. 1968. Observations on some Holocene glacier fluctuations in west Greenland. Meddelelser om Gronland, Bd. $165, \mathrm{Nr} .6$.

Westgate, J. A. 1967 . Surficial geology of the Foremost-Cypress Hills area, Alberta. Alberta. Research Council.

Bulletin 22.
Whittecar, G. R., and Mickelson, D. M. 1977. Sequence of till deposition and erosion in drumlins. Boreas, Vol. 6, No. 2, p. 213-17.

Wright, H. E., jr. I976. Ice retreat and revegetation in the western Great Lakes area. (In Mahaney, W. C., ed. Quaternary stratigraphy of North America. Stroudsburg, Pa., Dowden, Hutchinson, and Ross, p. I I 9-32.) 